\title{
小児上腕骨外顆偽関節に対する骨接合術の検討
}

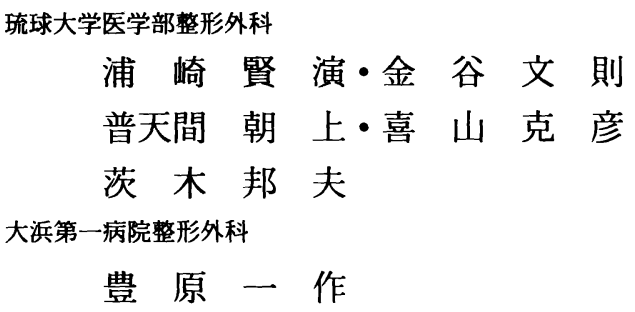

\section{Osteosynthesis for Nonunion of Lateral Humeral Condyle in Children}

\author{
Kenhiro Urasaki, Fuminori Kanaya, Chojo Futenma, \\ Katsuhiko Kiyama, and Kunio Ibaraki \\ Department of Orthopedic Surgery, School of Medicine, \\ University of the Ryukyus, Okinawa, Japan

\section{Issaku Toyohara} \\ Ohama Daiici Hospital, Okinawa, Japan
}

\begin{abstract}
We report the surgical results of osteosynthesis for the non union of the lateral humeral condyle in three children, two girls and one boy aged 2 years and 3 months, 3 years and 5 months and 12 years 1 month respectively. All patients showed limitation of the range of motion and lateral instability. One girl showing ulnar nerve palsy had both varus and valgus instability. Two patients had localized tenderness at the nonunion site.

Osteosynthesis with a iliac bone graft was performed and bone union was achieved in all cases. Follow-up period after operation was 1 year, 3 years 9 months, and 5 years. The range of motion of the elbow decreased $10^{\circ}$, no change, and increased $10^{\circ}$ in one patient each. Pain and instability disappeared in all cases. Ulnar nerve palsy seen in one patient improved after surgery.

Our short-term results of osteosynthrosis are satisfactory. However, post-operative roentgenogram revealed mild arthrosis and irregular epiphysis in each. Long-term follow - up is necessary after the osteosynthesis of the nonunion of the lateral humeral condyle in children.
\end{abstract}

Key words : nonunion of the lateral humeral condyle in children (小児上腕骨外顆偽関節), osteosynthesis（骨接合術）

はじめに

小児上腕骨外顆偽関節に対し骨接合術を行うことに は賛否両論がある．今回骨接合術を行った陳旧性小児 上腕骨外顆偽関節の 3 例について検討した.
対 象亡術式

女児 2 例男児 1 例で手術時年齢はそれぞれ 12 歳 1 カ月， 2 歳 3 力月， 3 歳 5 力月であった。初期治療は ギプス固定が 2 例, 手術が 1 例であった. 3 例とも可 動域制限と外反動摇性を認め, うち 1 例は内反動摇性 
症例 1 .

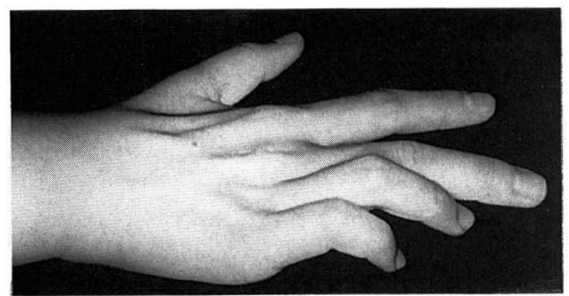

図1.

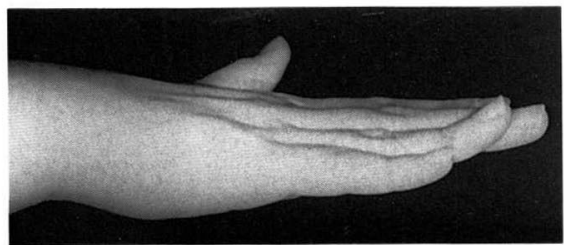

図3.

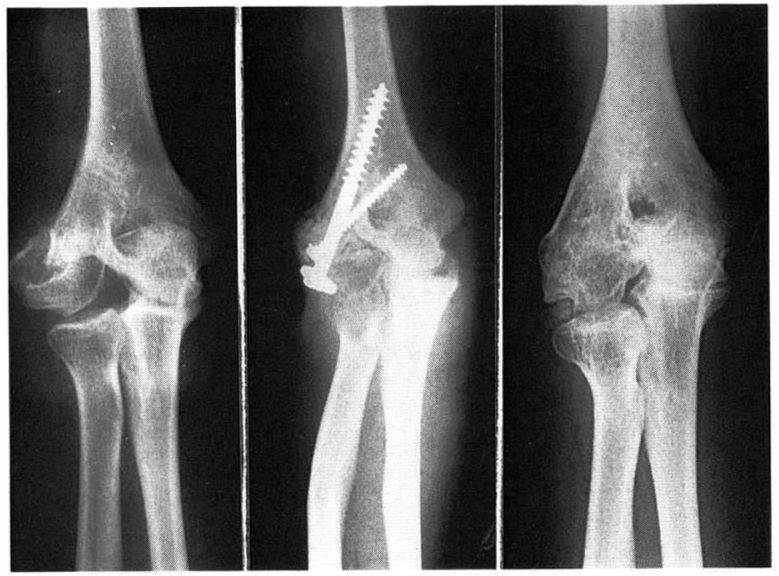

図 $2 a$.

図 2 b.

図 2 c.

症例 1.12 歳 1 力月 女児

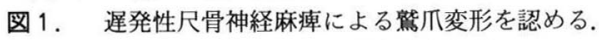

図 $2 a$ ，術前：外顆骨片の回旋転位を認める.

図 2 b. 術直後 : 骨片整復後, 腸骨移植, スクリュ一固定を行った.

図 $2 \mathrm{c}$. 術後 5 年: 骨癒合拈よび軽度の関節症性变化を認めた.

図 3. 鷲爪変形は消失し, 握力は健側の $85 \%$ まで回復した.

症例 2 .

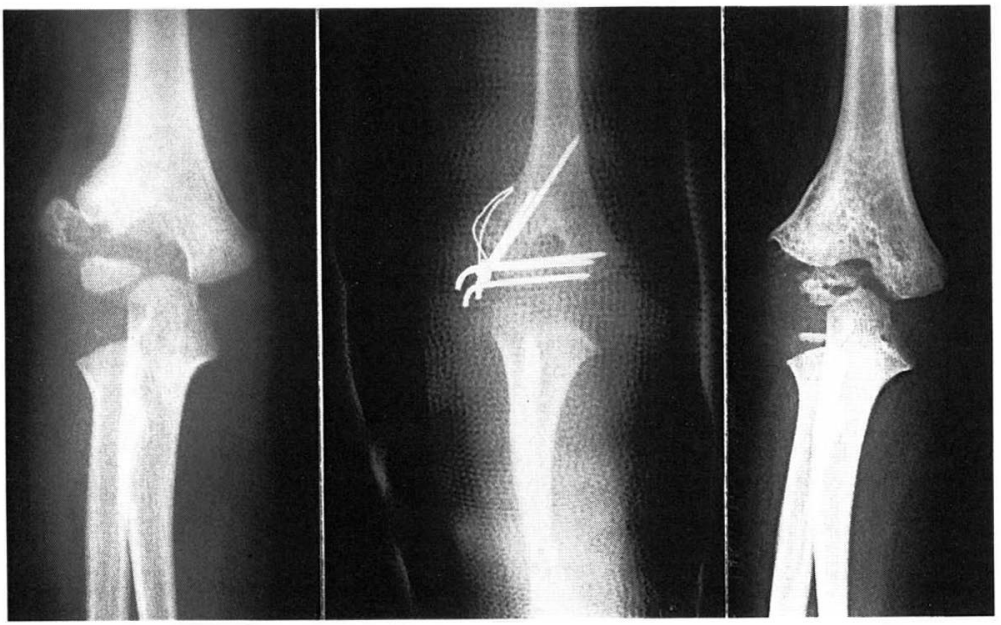

図 4 a.

図 4 b.

図 $4 \mathrm{c}$.

症例 2. 2 歳 3 力月 女児

図 4 a. 術前 : 外顆骨片の橈側転位を認めた。

図 4 b. 術直後: 腸骨移植と tension band wiring を行った.

図 4 c. 術後 1 年 : 骨癒合および骨端核の不整を認めた. 
症例 3 .

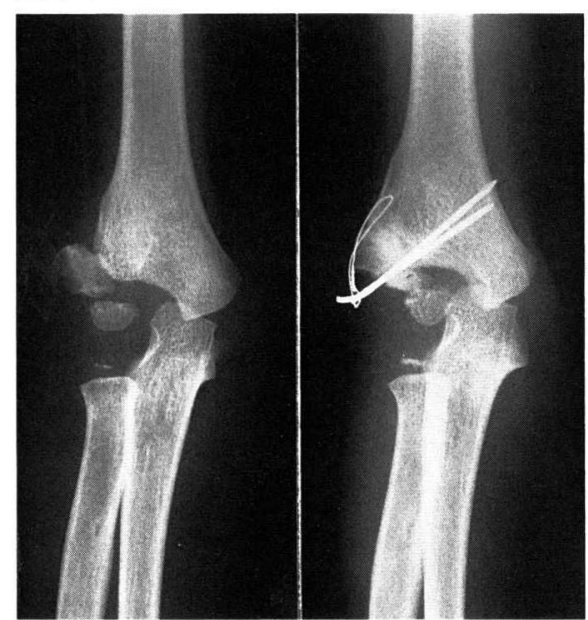

図 5 a.
図 5 b.

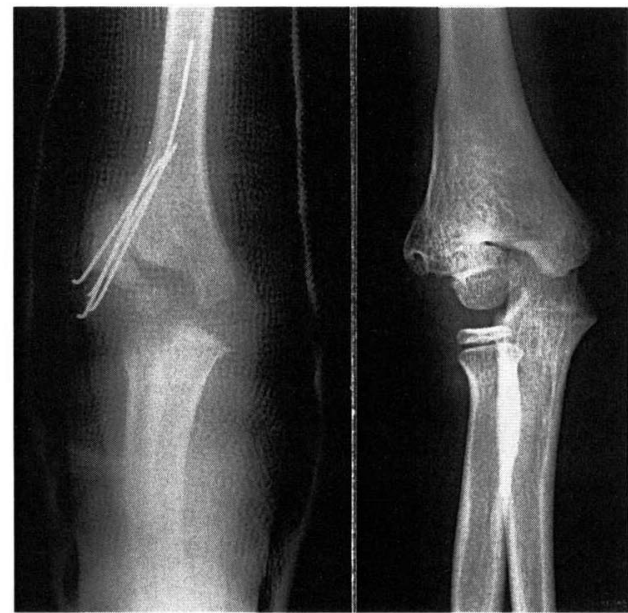

図 $5 \mathrm{~d}$.

症例 $3: 3$ 歳 5 力月 男児

図 5 a . 術前 : 外顆骨片の橈側転位を認めた。

図 5 b. 術直後: 腸骨移植と tension band wiring を行った.

図 5 c . 抜釘後骨折, 再手術後: 腸骨移植とキルシュナー鋼線固定を行った.

図 $5 d$. 初回術後 3 年 9 力月: 骨癒合を認める.

あ認めた． 2 例で偽関節部に圧痛を認め，うち 1 例で 外反強制時に疼痛が出現し, 遅発性尺骨神経麻疸も合 併していた，手術は 2 例に腸骨移植と tension band wiring を行い， 1 例に腸骨移植とスクリュ一固定を 行った．受傷から手術までの期間はそれぞれ 10 年 1 力月，10 力月， 9 力月であった。術後観察期間はそ れぞれ 5 年, 1 年, 3 年 9 カ月であった.

\section{結}

果

3 例とも骨癋合が得られたが， 1 例で抜釗後転倒し 再骨折したため腸骨移植とキルシュナー鋼線固定を行 い 6 力月後（初回術後 3 年 9 力月後）骨癒合を得た. 可動域は術前之比較し, それぞれ 10 度減少, 不変, 10 度改善であった。 3 例とも動摇性と疼痛は消失し た. X線像で 1 例に関節症性变化を認め, 1 例に骨端 核不整を認めた。尺骨神経麻痺を呈した 1 例は症状の 改善を認めた。

\section{症}

例

【症例 $1 】 12$ 歳 1 力月女児.

現病歴：2 歳時に右上腕骨外顆骨折を受傷, 近医にて ギプス固定を受け偽関節となるも疼痛が軽減したため
放置していた. 11 歳時に右手の握力低下を自覚, 12 歳時に熟爪变形が出現し当科受診となった（図 1 ).

現症: 可動域は伸展一 5 度, 屈曲 130 度で外反・内反 動摇性を認め, 偽関節部の圧痛および外反強制時の疼 痛を認めた。また尺骨神経麻痺を認め握力は $11 \mathrm{~kg}$ （健側の $58 \%$ ）であった。

X線像 : 外顆骨片の回旋転位を認めた（2 a ）.

手術法 : 骨片整復後, 腸骨移植, スクリュ一固定およ び尺骨神経前方移動術を行った（図 2 b ).

術後経過: 術後 5 年, 可動域は伸展 -10 度, 屈曲 125 度と 10 度減少したが, 関節動摇性・疼痛は消失しス ポーツ活動に支障はない。敦爪変形は消失し，握力は $22 \mathrm{~kg}$ （健側の 85\%）に回復した（図 3 ）.X線像で骨 瘉合および軽度の関節症性変化を認めた (図 $2 \mathrm{c}$ ).

【症例 2】 2 歳 3 力月女児.

現病歴：1 歳 5 力月時に右上腕骨外顆骨折を受傷. 近 医にて観血的整復固定術を受けたが， 7 力月後骨癒合 が得られないため当科紹介となった。

現症: 可動域は伸展 0 度, 屈曲 125 度で外反動摇性, 偽関節部の圧痛を認めた。

X 線像：外顆骨片の橈側転位を認めた（図 4 a).

手術法: 腸骨移植と tension band wiring を行った 
(図 4 b).

術後経過: 術後 1 年, 可動域は变化なく, 関節動摇性・ 圧痛は消失した，X線像で骨癒合および骨端核の不整 を認めた（図 $4 \mathrm{c}$ ）。

【症例 3 】 3 歳 5 力月男児.

現病歴：2 歳 8 力月時に右上腕骨外顆骨折を受傷. 近 医にてギプス固定を受けたが， 7 力月後骨瘉合が得ら れないため当科紹介となった。

現症：可動域は伸展 0 度，屈曲 115 度で外反動摇性を 認めたが疼痛はなかった。

X線像 : 外顆骨片の橈側転位を認めた（図 5 a).

手術法：腸骨移植と tension band wiring を行った (図 5 b).

術後経過：骨瘰合を得，拔釘も行われたが，術後 6 力 月に転倒し同部位を骨折したため腸骨移植とキルシュ ナー鋼線固定を行った (図 $5 \mathrm{c}$ ). 初回術後 3 年 9 力 月, 可動域は伸展 0 度, 屈曲 125 度之術前より 10 度 改善し，関節動摇性は消失，X線像で骨癒合を認めた (図 $5 \mathrm{~d}$ ).

\section{考察}

小児上腕骨外顆偽関節に対して骨接合術を行うか否 かは，術後可動域の減少や外顆骨片の無腐性壊死など 種々の合併症を来すとの報告ああり現在であなお意見 の分かれるところである. Jakobら ${ }^{5)}$, Hardacre ${ }^{3)}$ は 3 週以上経過した例に骨接合術の適応はないと述べ ている。，一方積極的に骨接合術を勧める意見も多 (1)2)677)8 (10)1112) 島田ら ${ }^{9)}$ は成人では肘関節に動摇性 や疼痛を自覚する症例に対してのみ手術を行い，小児 では骨片転位がある症例であ整復後骨接合を行えば成 長と共にリモデリングがおこり，関節面の適合性が改 善し最終的に可動域制限は問題とならないので手術を 行うべきであると述べている．伊藤ら ${ }^{4)}$ は受傷後 1 年 未満であれば，骨片に付着する軟部組織の剥離を少な くし，中枢骨幹端を骨膜下に剥離展開して整復すれば ほぼ満足すべき整復が得られ，術後可動域の減少およ び外顆骨端核の無腐性壊死を防止できると述べている. また，受傷後 1 年以上でも偽関節部の対向が比較的良 好で外顆骨片が比較的大きな症例に対しては積極的に 骨接合術をすべきであると述べている，私たちは骨端 線閉鎖前の小児外顆偽関節に対して, 全例で動摇性・ 疼痛を認めたため, 外顆骨片の大きさには関わらず骨
接合術を行っており，整復操作で軟部組織の剥離を最 小限に止め，骨端線は合わせる程度とし過矯正に注意 し手術を行っている. 今回私たちの症例では術後可動 域の減少を 1 例, X線像で軽度の関節症性変化, 外顆 骨片の骨端核の不整を各 1 例に認め, 今後長期の経過 観察が必要と考えられた.

\section{ま と め}

1. 小児の上腕骨外顆偽関節 3 例に対し骨接合術を 行った.

2. 全例骨瘉合し，短期成績は比較的良好であった。

3. 軽度の関節症性変化や骨端核の不整を認めた症 例もあり，今後長期の経過観察が必要と考えられた。

\section{至 考 文 献}

1）阿部宗昭・他：小児上腕骨外顆骨折の治療一とくに成 績不良例の検討．日整会誌，51：1172-1173， 1977.

2) Flynn, J. C., et al. : Prevention and treatment of non - union of slightly displaced fractures of the lateral humeral condyle in children. J.Bone Joint Surg., 57-A : 1087-1092, 1975.

3) Hardacre, J. A., et al. : Fractures of the lateral condyle of the humerus in children. J.Bone Joint Surg., 53-A : 1083-1095, 1971.

4）伊藤恵康 - 他 : 陳旧性上腕骨外顆骨折の治療. 臨床整 形外科, $22: 175-183,1987$.

5) Jakob, R., et al. : Observations concerning fractures of the lateral humeral condyle in children. J. Bone Joint Surg., 57-B : 430-436, 1975.

6) Masada, K., et al. : Osteosynthesis for old, established non-union of the lateral condyle of the humerus. J. Bone Joint Suryg., 72- A : 32-40, 1990.

7）村田紳说・他：小児上腕骨顆骨折の偽関節形成に対す る骨移植術の経験. 臨床整形外科, $15: 628-632,1980$.

8）長岡 清-他：小児上腕骨外顆骨折一早期治瘾遷延例 の検討．中部整災誌，21：1047-1052，1978.

9）島田幸造・他：小児上腕骨外顆偽関節に対する骨接合 術一関節面のリモデリングを中心に一。 日时会誌 1 （1） $69-71,1994$

10）田島達也・他：上腕骨外顆偽関節に対する積極的手術 法の適応と成績. 日整会誌，57：1220-1221，1983.

11）田島達也：上腕骨外顆偽関節に対する治療法一筆者の 提唱した新手術法の適応と手技の要点一。整形外科 Mook, 54 : 174-185, 1988.

12) Wadworth, T. G., : Injuries of the capitular (lateral humeral condyle) epiphysis. Clin. Orthop., 85 : 127 $142,1972$. 